\title{
A MAJOR CALVING EVENT OF JAKOBSHAVNS ISBRÆ, WEST GREENLAND, ON 9 AUGUST 1982
}

\author{
By W. EPPRECHT
}

(Ottenbergstrasse 45, CH-8049 Zürich, Switzerland)

ABSTRACT. On 9 August 1982, the calving of a large ice mass, approximately $0.3 \mathrm{~km} \times 1.5 \mathrm{~km}$ in size, from Jakobshavns Isbræ was filmed. The event, which took place as the tide was rising, is described by means of picture sequences from the ciné film. First, a large transverse crevasse opened in the glacier. The subsequently detached piece then split into large blocks which toppled forward one after the other in the direction of the fjord, so that finally large, clean ice slabs lay in front of the glacier terminus. The tilting ice blocks pushed the whole mass of fjord water, together with the ice debris which floated on it, in the direction of the sea. The tilting processes had terminated after approximately $8 \mathrm{~min}$. Then a wave which had been reflected farther out in the fjord returned to the break-off zone, where it caused the formation of a large amount of ice debris and high jets of water.

ON the morning of 9 August 1982, I witnessed a major calving event of Jakobshavns Isbræ which terminates in Isf jord, east of Disko Bay, West Greenland. Weather conditions were superb. A large part of the calving was recorded by means of an $8 \mathrm{~mm}$ ciné camera. Since such events can only rarely be documented on ciné film, sequences of the film are presented below despite their relatively poor resolution (dimensions of the original frames: $5.3 \mathrm{~mm} \times 4.2 \mathrm{~mm}$ ). The sequence of events can be reconstructed on the basis of the shots taken at the times I-VIII Times I, VII, and VIII were recorded directly (local time of Jakobshavn), whereas times II-VI were determined on the basis of positions on the film strip and estimated lengths of interruptions between the scenes.

\section{Time}

$\begin{array}{ll}\text { I } & \quad 08 \mathrm{~h} 40 \mathrm{~min} \\ \text { II } & c .08 \mathrm{~h} 42 \mathrm{~min} \\ \text { III } & c .08 \mathrm{~h} 42 \mathrm{~min} 10 \mathrm{~s} \\ \text { IV } & c .08 \mathrm{~h} 44 \mathrm{~min} 00 \mathrm{~s} \\ \text { V } & \text { c. } 08 \mathrm{~h} 44 \mathrm{~min} 35 \mathrm{~s} \\ \text { VI } & \text { c. } 08 \mathrm{~h} 49 \mathrm{~min} 30 \mathrm{~s} \\ \text { VII } & 08 \mathrm{~h} 50 \mathrm{~min} \\ \text { VIII } & 08 \mathrm{~h} 55 \mathrm{~min}\end{array}$

At times I, VII, and VIII, additional pictures were taken with a Leica $24 \mathrm{~mm} \times 34 \mathrm{~mm}$ camera (Figs 1 and 2). Picture sequences starting at times III, IV, and $\mathrm{V}$ were enlarged from the cine film. The time differences between Figures 3,4 , and 5 were determined to the nearest $1 / 8 \mathrm{~s}$ by counting frames. The ciné film initially advanced at a rate of 16 frames/s, but after time III at 8 frames/s.

At $08.00 \mathrm{~h}$, I flew as a tourist on board a helicopter from Jakobhavn airport (Jlulissat) about $45 \mathrm{~km}$ west over Isfjord towards the front of Jakobshavns Isbræ. The calving front was at least $6 \mathrm{~km}$ long and lay at approximately long. $50^{\circ} 00^{\prime} \mathrm{W}$. The fjord was filled with numerous icebergs from its mouth in Disko Bay all the way to the glacier. Only in the middle section of the fjord was some open water visible between the icebergs. The rest of the water in the fjord was covered by a practically continuous layer of ice debris. The ice blocks were probably mostly clean and quite small; only occasionally could dirty patches be seen. Two types of iceberg were distinguishable: first, there were relatively large, tabular icebergs with almost vertical edges and dirty grey upper surfaces which had many vertical crevasses. These were clearly detached sections of the glacier front floating in their original vertical orientations. The second type were mostly clean with only very little morainic material, and were white to blue in colour. Smaller icebergs of this type had irregular shapes; the larger ones were frequently several hundred metres long and also had tabular shapes. After observing the glacier front, it became clear that the tabular icebergs of the second type were also originally vertical parts of the glacier tongue, but in this case had tilted after becoming detached from the glacier.

At about $08.30 \mathrm{~h}$ we landed on the ridge $1.5 \mathrm{~km}$ northwest of the glacier terminus. Here, at about $200 \mathrm{~m}$ a.s.l., the view towards the south-south-east was as shown in Figure 1. The distance to the farther glacier margin (centre of the picture) is approximately $14 \mathrm{~km}$. The nearer, northern margin is hidden behind the ridge in the foreground. However, the near margin could be seen from position $A$. The calving front is, according to Anon. (1985),

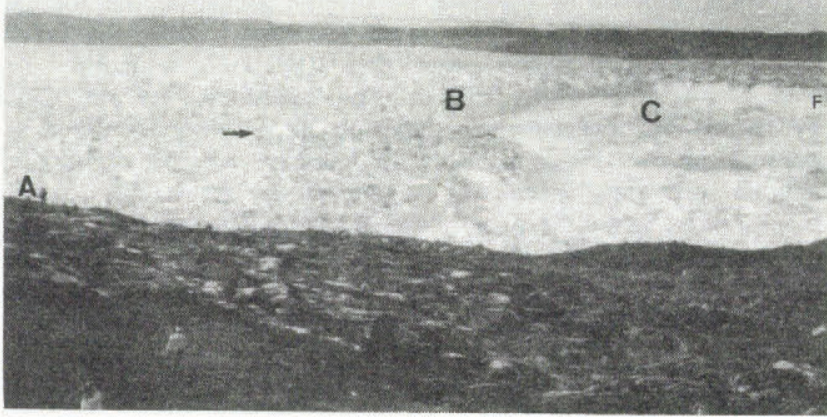

Fig. 1. Leica photograph at $08.40 \mathrm{~h}$. View towards the south-south-east across Jakobshavns Isbra. Distance to far glacier margin is approximately $14 \mathrm{~km}$. During the subsequent calving, the piece of glacier in front of the crevasse between $\mathrm{B}$ and $\mathrm{A}$ became separated. The wall $\mathrm{B}-\mathrm{C}$ is approximately $70 \mathrm{~m}$ high. To the right is the fjord surface covered with ice debris. The northern, near margin of the glacier is hidden behind the ridge in the foreground. 
approximately $70 \mathrm{~m}$ high and trends in a roughly north-south direction in the section $B-C$. Starting at $C$, the front trends in an east-west direction for some distance, and it was estimated to be $100 \mathrm{~m}$ high in this section.

At $08.40 \mathrm{~h}$, a crevasse became visible which started at the angle $B$ in the calving front and extended in a northerly direction as far as the arrow in Figure 1. The crevasse formed a continuation of the front segment B-C. During the next $10 \mathrm{~min}$, the crevasse lengthened rapidly towards the north. Subsequently, the part in front of the crevasse separated from the glacier. Figure 2 shows the situation at $08.50 \mathrm{~h}$, as seen from position A. Close to the

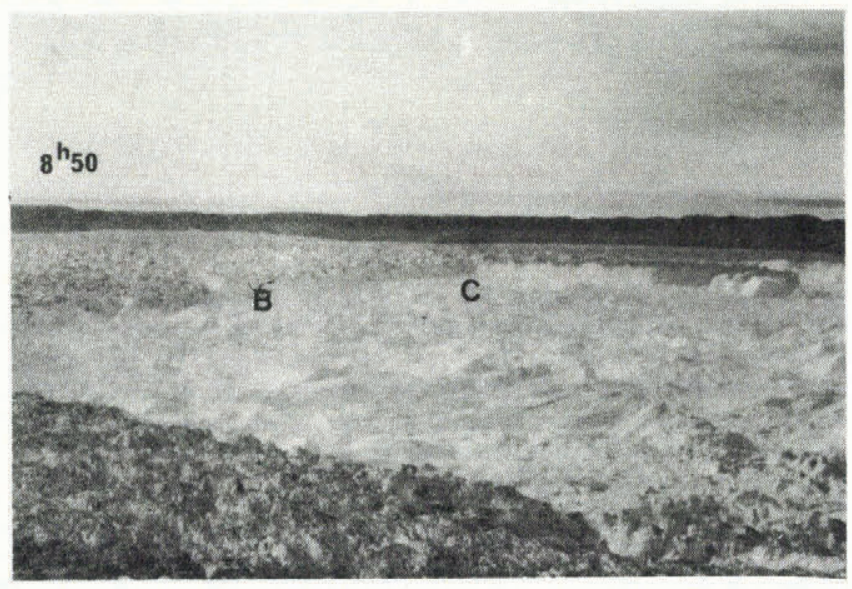

Fig. 2. Leica photograph at $08.50 \mathrm{~h}$ taken from position A. The part of the glacier which was still intact in Figure 1 has now disintegrated into large blocks. These toppled over during an $8 \mathrm{~min}$ time interval and can now be seen as clean slabs lying next to each other in the water of the fjord.

near glacier margin, a section of the glacier remained (lower left). Behind this, a $300 \mathrm{~m} \times 1500 \mathrm{~m}$ large block had "disappeared". The sequence of events was as follows: at about $08.42 \mathrm{~h}$, loud bangs resembling cannon shots were heard and, in the fracture zone north of $B$, movements could be seen (cracks becoming larger, pieces falling from the cliff). In addition, the crack lengthened rapidly and white jets (water or water-ice mixture?) shot out from it. From this moment in time (III) onwards, sections of the events were filmed, first from the same position as that in Figure 1 (Fig. 3a-d), and afterwards from position A (Figs 4 and 5).

The picture sequence in Figure $3 a-d$ shows the section of the crack north of $B$. In Figure $3 a$ jets spouting from the crack can be recognized as diffuse areas in the picture. A transverse lamella of ice was observed within the crack, and Figure $3 \mathrm{~b}-\mathrm{d}$ shows how this lamella subsequently fell over towards the right. This motion can easily be pinpointed by comparing the lamella's position in relation to the fixed point $\mathrm{D}$ on the stable part of the glacier. At the same time, another crevasse opened at $\mathbf{E}$ across the near side of the main crack. Simultaneously, the block of ice $H$ to the right of the new crevasse first shot up vertically (Fig. 3a-d) and then toppled over to the right (Fig. 4a-d). Its original upper surface (rough and moraine-covered) tipped over into a vertical orientation; the crevasse wall became a horizontal, snow-white, tabular surface. During the opening of this crevasse, smaller sections of the wall continued to fall down. Rocks and smaller morainic debris slid off the old glacier surface at $\mathrm{H}$ which became steeper and steeper.

During the rotation of block $\mathrm{H}$, more crevasses opened in the newly separated section of the glacier and, as a result, blocks $\mathrm{J}$ and $\mathrm{K}$ became free (Fig. 4). These then fell over, one after the other, like falling dominoes; their rotational axes were slightly different from each other (Fig. $4 \mathrm{~b}-\mathrm{d}$ ). Within $2 \mathrm{~min} 40 \mathrm{~s}$ (Figs $3 \mathrm{a}-5 \mathrm{~b}$ ), block $\mathrm{H}$ had rotated completely by $90^{\circ}$ and now lay flat. Even faster was the rotation of block L (Fig. 5), whereas block $\mathrm{J}$ tipped
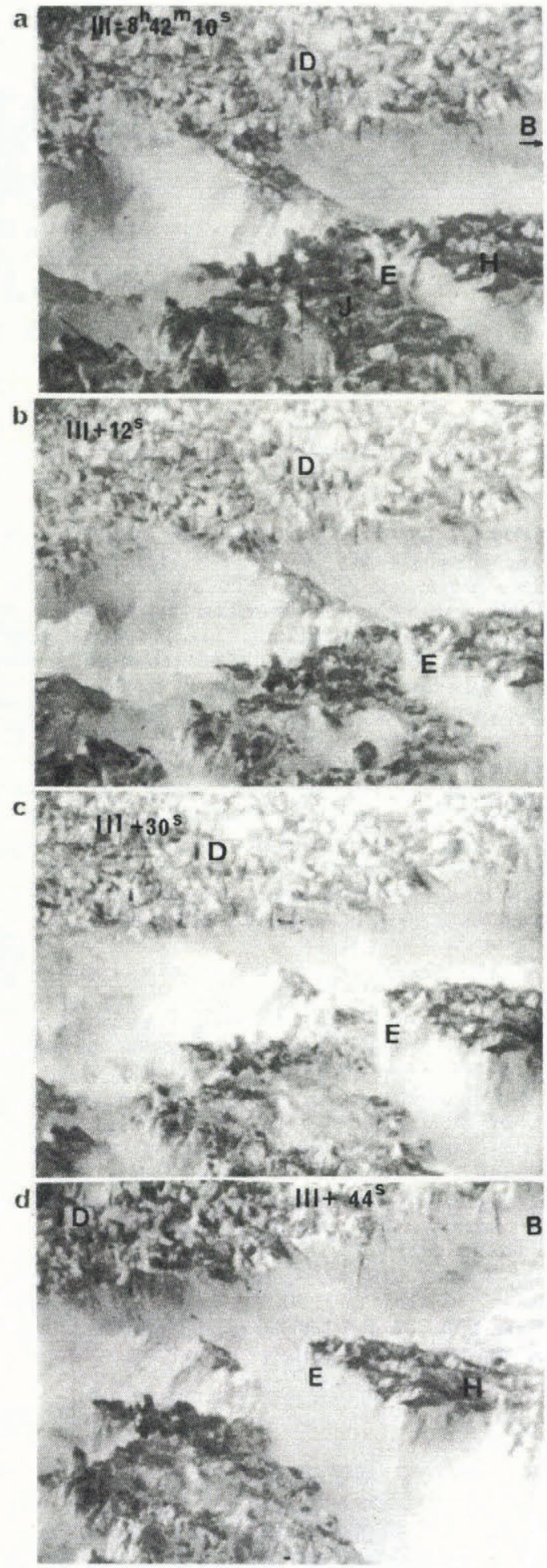

Fig. 3. Picture sequence from the cine film (original frame size $5.3 \mathrm{~mm} \times 4.2 \mathrm{~mm}$ ). Areas to the immediate north of point B (cf. Fig. 1), taken from position A. Upper half of image: stable glacier; from right to left: transverse crevasse opening, in which can be seen a cross wall (Fig. 3a) that tilts slowly towards the right (Fig. $3 b-d)$; note the fixed point D). The right-hand section of the near part of the glacier is also divided by a crevasse. The ice block $\mathrm{H}$ on the right with the corner $\mathrm{E}$ first shoots up to at least $70 \mathrm{~m}$ (Fig. $3 b$ and $c$ ) whereupon it starts to tilt towards the right. Water jets rise from the crevasses. The time intervals between the frames were determined from the speed of the cine film (Fig. $3 a=$ time III $=08 \mathrm{~h}$ $40 \mathrm{~min} 10 \mathrm{~s} ;$ Fig. $3 d=44 \mathrm{~s}$ (ater). 
a

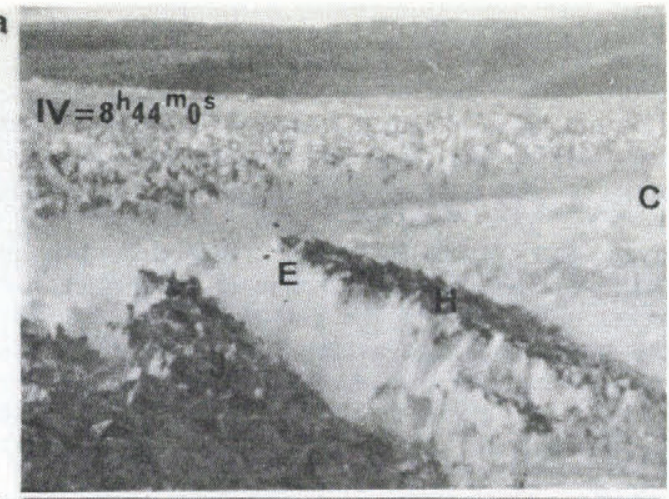

b

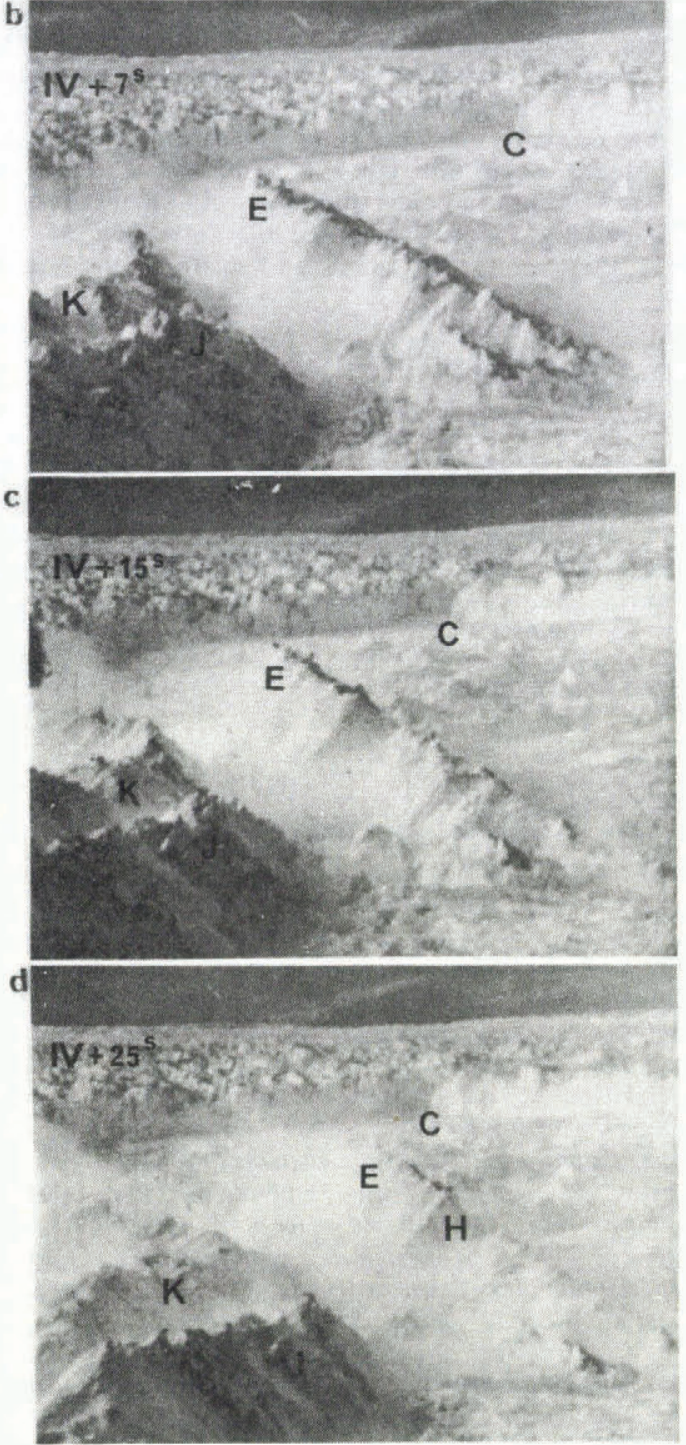

Fig. 4. Position as in Figure 3 but about twice the angle of view. Figure $4 a$ : $76 \mathrm{~s}$ after Figure $3 d$. Block $\mathrm{H}$ continues to tilt towards the right. Simultaneously, more crevasses form in the near-left area of the glacier. Formation of the blocks $\mathrm{J}, \mathrm{K}$, and $\mathrm{L}$ which also begin to tilt.

relatively slowly. Within about $7 \mathrm{~min}$, not only did the part which had become separated from the glacier by the main fissure disintegrate into blocks, but these blocks had also toppled over. Afterwards, they all lay as large white slabs, several hundred metres across, closely packed together in the fjord (Fig. 2). Their surfaces were relatively smooth and very clean. Quite a small piece originating from the glacier margin (lower right in Figure 2) moved out into the fjord without tipping over.

During the formation of the blocks and the tilting processes a loud noise was heard, accentuated by thunder claps which were probably caused by the opening of the crevasses. Many white jets of water shot up here and there, especially at the calving front $\mathrm{C}-\mathrm{B}$ (Fig. $5 \mathrm{~b}$ and $\mathrm{c}$ ), where they reached heights of at least $200 \mathrm{~m}$.

At the same time as the rotational movements of the blocks became prominent, the layer of ice debris in the fjord in front of the original glacier front started to move.

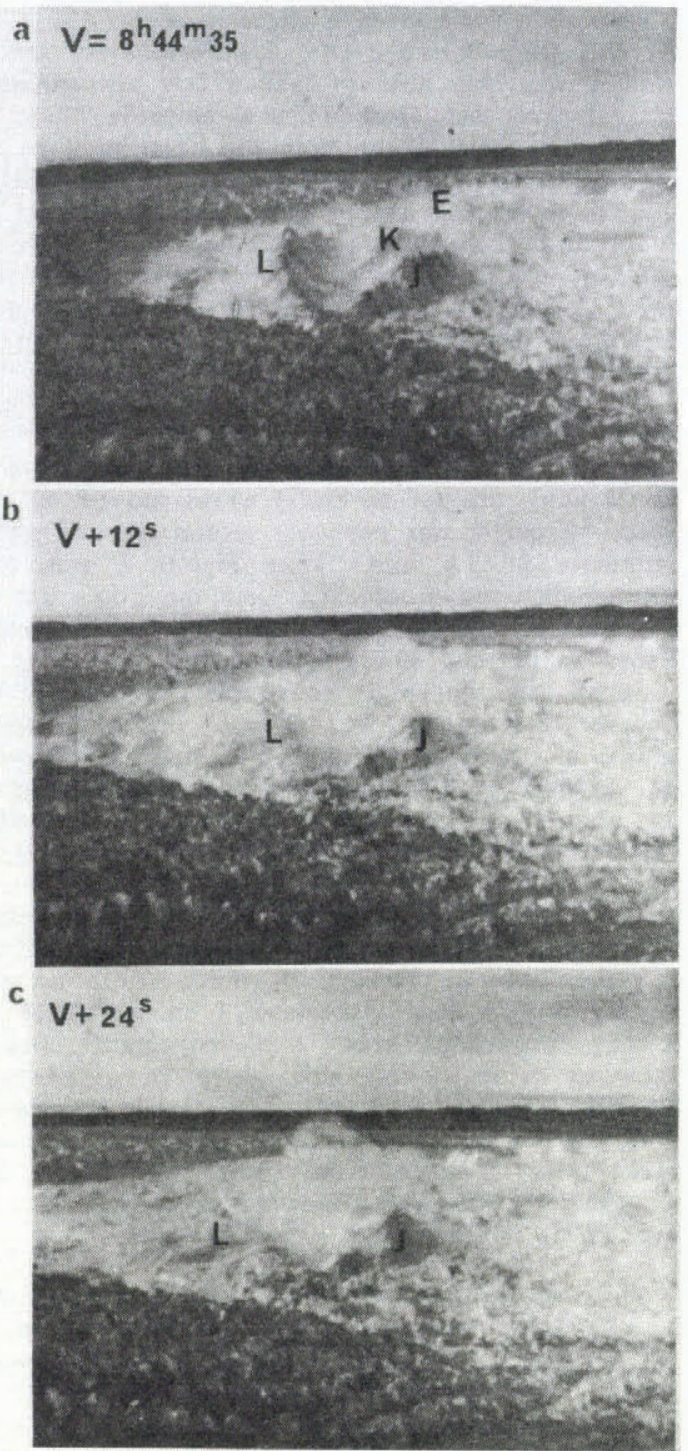

d $V I=c a .8^{h_{1}} 49^{m_{30}}$ s

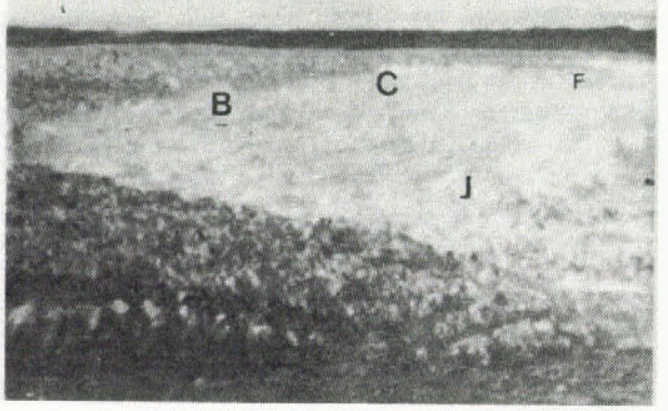

Fig. 5. Position as in Figure 3. Angle of view considerably larger than in Figure 3. Block $\mathrm{H}$ tilts further, and $2.5 \mathrm{~min}$ after its separation has already rotated by $90^{\circ}$ (Fig. 5 b). The picture sequence in Figure 5a-d shows that the blocks $\mathrm{H}$ (with corner $\mathrm{E}$ ), $\mathrm{J}, \mathrm{K}$, and $\mathrm{L}$ tip over with somewhat differently oriented horizontal axes. Block $\mathrm{L}$ rotates very rapidly, block $\mathrm{J}$ most slowly. Figure $5 b$ shows a water jet at the former calving front $\mathrm{B}-\mathrm{C}$. Figure $5 d$ was taken $0.5 \mathrm{~min}$ before Figure 2. 
The motion was (a) quite turbulent in the vicinity of the tilting processes, and (b) homogeneous, almost like a continuous, rigid carpet in a direction further out towards the fjord. The cine film shows that the carpet of ice debris (which was already present before the start of these events) had not piled up in front of the moving blocks. This means that the blocks did not exert a ploughing action on the ice debris but rather that they worked on the water in the fjord, pushing it forward as a single mass.

At this stage in the events, I unfortunately ran out of film and I was only able to take a few still photographs. These document that from $08.50 \mathrm{~h}$ onwards there was a relatively quiet phase in the break-off/rotation zone. Shortly before the return flight, one last picture was taken (time VIII). This shows that at $08.55 \mathrm{~h}$ there was again intense movement in the debris area. In the vicinity of blocks $\mathrm{J}, \mathrm{K}$, and $\mathrm{L}$, large displacements of the icebergs can be observed compared to Figure $2(08.50 \mathrm{~h})$. In addition, high wide clouds from water jets can be seen in the area south of $B$ and west of $\mathbf{c}$. These phenomena document the terminal stage of the events but I was unable to observe it sufficiently accurately.

Shortly after the widening of the main crack (i.e. around $08.42 \mathrm{~h}$ ), one (or several?) waves moved out through the fjord. Its height was probably several tens of metres. At approximately $08.53 \mathrm{~h}$, soon after Figure 2 was taken, a high but shallow wave returned from the outer part of the fjord. When it reached the calving front, the water level there rose to at least $30 \mathrm{~m}$, approximately half-way up the front. Spray jets shot high above the front $(08.55 \mathrm{~h})$. The wave caused the tilting blocks to crash into each other, and the sound of ice being ground into fine debris was most evident. Therefore, it appears that the fine ice debris was formed mainly in the final stage by the reflected wave. This reflection of the wave might have occurred at the ice barrier at the mouth of the fjord.

It is interesting to note that calving events from tidewater glaciers can be initiated by tidal variations in sealevel, which exert a varying buoyancy force on the ice. During my stay in West Greenland, I unfortunately did not gather any information about tidal movements. Because of the lack of a registering tide gauge in Jakobshavn, no records are available. However, Mr D. Christensen of the Nautical Department of the Meteorological Institute of Denmark later calculated the tidal movements on $8-9$ August 1982 for me. The following deviations from normal sea-level $(0 \mathrm{~m})$ at Jakobshavn were calculated:

8 August 1982: high tide at $23.04 \mathrm{~h} ; 1.20 \mathrm{~m}$ above $0 \mathrm{~m}$;

9 August 1982: low tide at $05.16 \mathrm{~h}$; $0.85 \mathrm{~m}$ below $0 \mathrm{~m}$; high tide at $11.20 \mathrm{~h} ; 0.45 \mathrm{~m}$ above $0 \mathrm{~m}$.

Therefore, during the night before the calving event described above, a relatively high tidal maximum was followed by a surface-level lowering of $2.05 \mathrm{~m}$. After this, the water level rose again, and therefore the calving occurred roughly half-way between low and high tide. Possibly, the crack visible in Figure 1 and north of $\mathbf{B}$ had formed during the marked water-level change the night before. I was unable to establish whether, and to what extent, the water-level changes at the calving front differed from those in
Jakobshavn. Contrary to the earlier view that Jakobshavns Isbræ flows over bedrock all the way to the calving front (e.g. Bauer, 1968), it now appears certain that the lower parts of this glacier are afloat for several kilometres. Kollmeyer (1980) was able to measure half-daily vertical oscillations of the glacier surface of up to $1.8 \mathrm{~m}$ at a distance of $1 \mathrm{~km}$ up-glacier from the calving front. Echelmeyer and Harrison (1985) established tide-induced surface-altitude variations of $1.5-3 \mathrm{~m}$ at the glacier terminus. The vertical movements of the glacier surface, therefore, are about the same magnitude as the tide-water level variations. This supports the fact that the end of the glacier tongue is afloat. Since the glacier surface displays many transverse crevasses, conditions are good for the widening of these into large calving fissures. The tide-induced stresses at the ends of the crevasses are periodically reversed - a process which can, according to the laws of fracture mechanics, lead to sudden extensions of these cracks. According to Kollmeyer (1980), Jakobshavns Isbræ is probably cold. Ice below the pressure melting-point is brittle, so that smooth vertical breaks occur through the glacier as a whole. Bauer (1968) gave $750 \mathrm{~m}$ as the thickness of Jakobshavns Isbræ near the calving front. Therefore, the formation of tabularshaped icebergs, several hundred metres high, is quite possible.

\section{ACKNOWLEDGEMENTS}

I should like to thank Professor Dr D. Vischer, Professor Dr H. Röthlisberger, and Dr K. Hutter, of the Versuchsanstalt für Wasserbau, Hydrologie und Glaziologie of the ETH Zürich for encouraging me to write this contribution, and for their extensive help during its preparation. Thanks are also due to S.P. Ineichen, who made the enlarged prints of the cine frames. I also wish to thank $\mathrm{Mr}$ D. Christensen, Denmark, for calculating the water levels at Jakobshavn.

\section{REFERENCES}

Anon. 1985. Eisberge, den Riesen auf der Spur. Geo, p. 194-95.

Bauer, A. 1968. Accélération de l'écoulement des glaciers groenlandais vers leur front et détermination de leur débit solide. Expédition Glaciologique Internationale au Groenland, Vol. 2, No. 3, p. 55-78.

Echelmeyer, K., and Harrison, W. 1985. Tidal and seasonal fluctuations in the motion of Jakobshavns Glacier and their relation to basal sliding. American Geophysical Union. Chapman Conference on Fast Glacier Flow, Whistler Village, Canada, May, 1986. Abstracts, p. 23.

Kollmeyer, R.C. 1980. West Greenland outlet glaciers: an inventory of the major iceberg producers. [Union Géodésique et Géophysique Internationale. Association Internationale des Sciences Hydrologiques. Commission des Neiges et Glaces.] Atelier Inventaire Mondial des Glaciers. Actes de l'Atelier de Riederalp. Suisse, 17-22 septembre 1978, organisé par le Secrétariat Technique Temporaire pour l'Inventaire Mondial des Glaciers, p. 57-65. (IAHS-AISH Publication No. 126.) 